\title{
The Number and Types of Bacteria in the Bali Cattle's Vagina during Estrus and Pregnant
}

\author{
Ketut Tono P.G1 ${ }^{1}$ Putu Henrywaesa Sudipa², I Gusti Ketut Suarjana ${ }^{3}$ \\ ${ }^{1}$ Veterinary Bacteriology and Mycology laboratory, Veterinary Pathobiological Department, \\ Faculty of Veterinary Medicine, Udayana University, Bali, Indonesia \\ E.mail : ketut_tono@unud.ac.id \\ ${ }^{2}$ Veterinary Bacteriology and Mycology laboratory, Veterinary Pathobiological Department, \\ Faculty of Veterinary Medicine, Udayana University, Bali, Indonesia \\ E.mail : henrywaesa@unud.ac.id \\ ${ }^{3}$ Veterinary Bacteriology and Mycology laboratory, Veterinary Pathobiological Department, \\ Faculty of Veterinary Medicine, Udayana University, Bali, Indonesia \\ E.mail :kt_suarjana@unud.ac.id
}

Corresponding Author: ketut_tono@unud.ac.id

\begin{abstract}
Bali cattle have very good potential for meat and calf supply, because they have good adaptability with good quality reproductive properties. However, good reproductive nature is threatened by diseases caused by bacteria. This study aims to determine the number and types of bacteria in the vagina of Bali cattle that are estrus and pregnant. Sample using vaginal swabs from 30 cows. The sample consisted of 10 swabs from non-estrus and not pregnant (control / normal) cattle, 10 swabs from estrus cows, and 10 swabs from pregnant cows. After the swab is carried out using a cotton bud, the results of the swab are stored in Stuart transport media. Samples planted in blood media to be identified and the number of colonies counted, then followed by Gram staining and biochemical tests then the results were presented descriptively. The result is the highest number of estrous cow colonies (1034 colonies), compared to nonestrous and non-pregnant cows (407 colonies) and pregnant (376 colonies). This type of bacteria is dominated by Klebsiella sp. (42.85\%), Eschericia coli (28.7\%), Streptococcus sp. (14.28\%) and Bacillus sp. (14.28\%).
\end{abstract}

Keywords: Bacteria, Bali Cattle, Vagina Swab

\section{INTRODUCTION}

Bali cattle (Bos sondaicus, Bos javanicus, Bos / Bibosbanteng) are one type of cattle that is important for the development of the industry to support tourism in Bali and Indonesia in general. This is because Bali cattle have very good potential for the supply of meat and calf because they have good adaptability with 
good quality reproductive properties [7]. However, this good reproductive nature is threatened by diseases caused by bacteria. One result of a bacterial infection is abortion. Abortion is a major problem for farmers due to loss of foetus which is sometimes followed by diseases of the uterus and prolonged sterility. According to [9], the causative agents of abortion are classified into several groups, namely physical, genetic, nutritional, chemical, drug, poisoning, hormonal, and disease. While the disease is generally caused by bacteria, viruses, fungi and protozoa. Bacterial infection is very detrimental to Bali cattle, in this case the bacteria in the reproductive tract of female cows, at the time of estrus where the cow is ready to be mated and when pregnant which is capable of causing abortion. Therefore, it needs to be investigated in this case the number of bacteria and what types of bacteria are in the reproductive tract of female cows, so that prevention and treatment can be done early so that bacterial infections during estrus and pregnancy can be addressed.

\section{MATERIALS AND METHODS}

The research was starting in May 2019, samples were taken at Sobangan
Village, Badung, Bali. Then the samples were examined at the Laboratory of Bacteriology and Mycology in the Faculty of Veterinary Medicine, Udayana University.Samples using vaginal swabs from 30 cows. The sample consisted of 10 swabs from non-estrus and not pregnant (control / normal) cattle, 10 swabs from estrus cows, and 10 swabs from pregnant cows. After the swab is carried out using a cotton bud, the results of the swab are stored in Stuart transport media. Samples planted in blood media to be identified and the number of colonies counted, then followed by Gram staining and biochemical tests then the results were presented descriptively.

\section{RESULTS AND DISCUSSION}

The number of colonies that grows most is atestrus cows, this is inversely proportional to the revelation [6], where the results of the study show that during estrus where the hormone estrogen dominates during the follicular phase, there is an increase in leukocyte migration to the uterine lumen thereby increasing bactericidal activity. But the opposite results were obtained in the study [2], where the bacteria isolated during the follicular phase (proestrus and estrus) only $22.47 \%$ compared to the luteal phase 
(metestrus and diestrus) which is $77.53 \%$ of estrous cycle.

the total number of bacteria in the normal

Table1.The Number of Colonies Growthin a Media Taken from a Normal Cow and not Estrus (Control)

\begin{tabular}{cc}
\hline No. Sample & Number of Colonies \\
\hline A1 & 33 \\
A2 & 99 \\
A3 & 40 \\
A4 & 10 \\
A5 & 10 \\
A6 & 95 \\
A7 & 39 \\
A8 & 20 \\
A9 & 93 \\
A10 & 31 \\
\hline Total Colony & 470 \\
\hline Average & 47 \\
\hline
\end{tabular}

Table 2. The Number of Colonies Growth in a Media Taken from The Pregnant Cow

\begin{tabular}{cc}
\hline No. Sample & Number of Colonies \\
\hline B1 & 36 \\
B2 & 12 \\
B3 & 33 \\
B4 & 29 \\
B5 & 54 \\
B6 & 11 \\
B7 & 6 \\
B8 & 36 \\
B9 & 60 \\
B10 & 99 \\
\hline Total Colony & 376 \\
\hline Average & 37,6 \\
\hline
\end{tabular}


Table 3. The Number of Colonies Growth in a Media Taken from Anestrus Cow

\begin{tabular}{cc}
\hline No. Sample & Number of Colonies \\
\hline E1 & 11 \\
E2 & 55 \\
E3 & 181 \\
E4 & 110 \\
E5 & 60 \\
E6 & 47 \\
E7 & 176 \\
E8 & 106 \\
E9 & 190 \\
E10 & 98 \\
\hline Total Colony & 1034 \\
\hline Average & 103,4 \\
\hline
\end{tabular}

Table 4. Type of Bacteria and Percentage of Bacteria on Sample

\begin{tabular}{cc}
\hline Bacteria & Percentage $(\%)$ \\
\hline Eschericia coli & 28,7 \\
Streptococcus $s$. & 14,28 \\
Klebsiella $s p$. & 42,85 \\
Bacillus $s p$. & 14,28 \\
\hline
\end{tabular}

The smallest number of bacterial colonies in this study was shown by pregnant Bali cows, this is consistent with the study [6], where cows that have 3 months gestational age were successfully isolated by bacteria only $12.94 \%$ of the total bacterial isolate, then the greater the gestational age, the number of bacteria that were successfully isolated was less where at 6 months gestation age, only $11.18 \%$ were successfully isolated and by age of 9 month only $8.82 \%$ of the total isolate was successfully isolated. This was added by [6] where the number of isolates that were successfully isolated was more obtained at the age of early pregnancy (42.08\%) compared to the age of late pregnancy $(15.83 \%)$.

The four types of bacteria that grow are bacteria that are often found in the vaginal area of a cow, according to [4] Microbial flora of the healthy cow's 
reproductive tract consists of a combination of aerobic microorganisms, facultative anaerobes, and mandatory anaerobes. Lactobacilli is found to be present in low amounts in bovine vaginal microbiota; in addition, Enterobacteriaceae is among the dominant population [5]. This is consistent with the results of research conducted which is Klebsiella sp. Enterobacteriaceae, and the number is most dominant among other bacteria. Then the dominant bacteria found in addition to Klebsiella sp. is E.Coli, which according to the study of [1] E. Coli is a normal flora that most commonly found in cattle. This is not surprising because sanitation, environmental conditions, the breeding system and general conditions of animals influence the colonization of the bacterial ratio of the vagina [8].

According to [6] at follicular phase (proestrus dan estrus) the most commonly isolated bacteria wereBacillus Spp. (22.58\%) followed byCorynebacterium Spp., Staphylococcus Spp. and Streptococcus Spp. (masing-masing 19.35\% ), E. coli and Salmonella (masing-masing $6.45 \%$ ), andMicrococcus and vaginal fungi $(3.23 \%$ each), shows the results of bacteria that were successfully isolated $18.24 \%$ from 170 isolated bacteria. At luteal phase (metestrus and diestrus) the most dominant bacteria wereStaphylococcus Spp. (19.05\%) followed byCorynebacterium Spp. (14.29\%), Bacillus Spp., E. coli andStreptococcus Spp. (11.90\% each), Micrococcus (9.52\%), Salmonella (7.14\%), andKlebsiella, Proteus andvaginal fungi ( $4.76 \%$ each), the bacteria were successfully isolatedis $24.71 \%$ from total of 170 bacteria isolate. [3] was successfully isolated E. coli (17.7\%), Klebsiella Spp. (5.81\%), Staphylococcus (12.79\%), andBacillus Spp. (9.30\%) from 40 pregnant cow sample. The result of our research is some of the bacteria that we successfully isolated showed the same result at research from [6] and[3], where we managed to isolated Klebsiella sp.for $42,85 \%$, followed by Eschericia coli for $28,7 \%$, and each from Streptococcus sp.type andBacillus sp. $14,28 \%$ from 30 sample, all of these bacteria always appear when viewed from several other studies.

\section{CONCLUSION}

The largest number of colonies grew on media whose specimens were taken from estrus Balicow vaginal swabs, totaling 1034 colonies, with an average of 103.4 colonies per sample. The number of colonies that 
grow sometimes varies with each study, but in general bacteria that can be isolated in the follicular phase (proestrus and estrus) are less than the luteal phase (metestrus and diestrus) or can be said in the not pregnant and estrous phases, then the number of bacteria that can isolated in pregnant cows decreases with increasing gestational age.

The bacteria that grew dominates by Klebsiella sp. for $42,85 \%$ from 30 sample, followed by Eschericia colifor 28,7\%, and each from Streptococcus $s p$. type and Bacillus sp. for $14,28 \%$. From several studies that have been done, the same bacteria also appear, but with different percentages.

\section{REFERENCE}

[1] Azawi OI,Omran SN,Hadad JJ. 2008. "A study of endometritis causing repeat breeding of cycling Iraqi buffalo cows". Reprod.Domest. Anim. 43(6):735-43.

[2] El-Jakee JA, Ahmed WM, El-Seedy FR,d El-Moez SA. 2008. Bacterial profile of the genital tract in female buffaloes during different reproductive stages. Global Vet. 2(1), 7-14.

[3] Jadon RS, Dhaliwal GS,Jand SK. 2005. Prevalence of aerobic and anaerobic uterine bacteria during peripartum period in normal and dystocia-affected buffaloes. Anim. Reprod. Sci.88(3-4): 215-224.

[4] Otero C, Silva De Ruiz C, Ibañez R, Wilde OR, De Ruiz Holgado AAP,
Nader-Macias ME. 1999. Lactobacilli and enterococci isolated from the bovine vagina during the estrous cycle. Anaerobe. 5:305-307.doi:

10.1006/anae.1999.0245.

[5] Otero C, Saavedra L, Silva De Ruiz C, Wilde O, Holgado AR, Nader-Macías ME. 2000. Vaginal bacterial microflora modifications during the growth of healthy cows. Lett. 31:251-254. doi: 10.1046/j.1365-2672.2000.00809. x.

[6] Patel CI, Panchal MT, Dhami AJ, Bhanderi BB,Mathakiya RA. 2019. Isolation of Bacteria from the Vaginal Aspirates of Cyclic, Acyclic, Endometritic and Pregnant Crossbred Cows.

Int.J.Curr.Microbiol.App.Sci.8(3): 536542

[7] Suranjaya IG, Ardika IN, Indrawati RR. 2010.Faktor-Faktor yang Mempengaruhi Produktivitas Sapi Bali di Wilayah Binaan Proyek Pembibitan dan Pengembangan Sapi Bali di Bali. Majalah Ilmiah Peternakan. 13(3): 8387.

[8] Sheldon IM, Noakes DE, Rycroft AN, Pfeiffer DU, Dobson H. 2002. Influence of uterine bacterial contamination after parturition on ovarian dominant follicle selection and follicle growth and function in cattle. Reproduction. 123:837-845. doi: 10.1530/rep.0.1230837.

[9] Toelihere MR. 2006. "Ilmukebidanan pada ternaksapi dan kerbau". Jakarta (Indonesia): Universitas Indonesia Press. 